Article

\title{
Combustion and Heat Release Characteristics of Biogas under Hydrogen- and Oxygen-Enriched Condition
}

\author{
Jun Li ${ }^{1}$, Hongyu Huang ${ }^{2, *}$, Huhetaoli ${ }^{2}$, Yugo Osaka ${ }^{3}$, Yu Bai ${ }^{2}$, Noriyuki Kobayashi ${ }^{1, *}$ \\ and Yong Chen ${ }^{2}$ \\ 1 Department of Chemical Engineering, Nagoya University, Nagoya, Aichi 464-8603, Japan; junli@energy.gr.jp \\ 2 Guangzhou Institute of Energy Conversion, Chinese Academy of Sciences, Guangzhou 510640, China; \\ taoli@ms.giec.ac.cn (H.); baiyu@ms.giec.ac.cn (Y.B.); chenyong@ms.giec.ac.cn (Y.C.) \\ 3 Faculty of Mechanical Engineering, Kanazawa University, Kakuma, Kanazawa, Ishikawa 920-1192, Japan; \\ y-osaka@se.kanazawa-u.ac.jp \\ * Correspondence: huanghy@ms.giec.ac.cn (H.H.); kobayashi@energy.gr.jp (N.K.); \\ Tel.: +86-20-870-48394 (H.H.); +81-52-789-5428 (N.K.)
}

Received: 10 May 2017; Accepted: 20 July 2017; Published: 13 August 2017

\begin{abstract}
Combustion and heat release characteristics of biogas non-premixed flames under various hydrogen-enriched and oxygen-enriched conditions were investigated through chemical kinetics simulation using detailed chemical mechanisms. The heat release rates, chemical reaction rates, and molar fraction of all species of biogas at various methane contents (35.3-58.7\%, mass fraction), hydrogen addition ratios (10-50\%), and oxygen enrichment levels (21-35\%) were calculated considering the GRI 3.0 mechanism and P1 radiation model. Results showed that the net reaction rate of biogas increases with increasing hydrogen addition ratio and oxygen levels, leading to a higher net heat release rate of biogas flame. Meanwhile, flame length was shortened with the increase in hydrogen addition ratio and oxygen levels. The formation of free radicals, such as $\mathrm{H}, \mathrm{O}$, and $\mathrm{OH}$, are enhanced with increase in hydrogen addition ratio and oxygen levels. Higher reaction rates of exothermic elementary reactions, especially those with $\mathrm{OH}$ free radical are increased, are beneficial to the improvement in combustion and heat release characteristics of biogas in practical applications.
\end{abstract}

Keywords: biogas; heat release; methane content; hydrogen addition; oxygen enriched

\section{Introduction}

With continuous depletion of fossil fuels and worsening pollution, research and development of renewable energy sources have attracted considerable interest [1-7]. Biogas can be produced using an anaerobic digester of biomass or biodegradable organic wastes. Compositions of biogas vary with the feedstock and the fermentation process [1-3]. The main compositions of biogas are methane $\left(\mathrm{CH}_{4}\right)$ and carbon dioxide $\left(\mathrm{CO}_{2}\right)$, as well as a small amount of water $\left(\mathrm{H}_{2} \mathrm{O}\right)$, nitrogen $\left(\mathrm{N}_{2}\right)$, and hydrogen $\left(\mathrm{H}_{2}\right)[3-5]$.

As an advantageous energy source, biogas is widely considered as a suitable fuel for heating facilities, power generation, and vehicles [8-15]. However, biogas possesses a relatively lower heating value (about $3000-6000 \mathrm{kcal} \cdot \mathrm{m}^{-3}$ ) and lower heat release rate than conventional fuels, which limits the application of biogas in combustion devices. Somehsaraei et al. [16] developed a steady state thermodynamic model for biogas application in $100 \mathrm{~kW}$ micro gas turbines. They found that mass flow and pressure ratio in the micro gas turbines are lower than those of the natural gas-fueled turbines. Furthermore, the total electrical efficiency decreases with decreasing $\mathrm{CH}_{4}$ content in biogas fuel, and the use of biogas negatively affects heat recovery. A three-dimensional computational fluid dynamic study on biogas flameless mode was developed by Hosseini et al. [17]. Although increasing preheated temperature positively affects the reduction of fuel consumption, a fuel with 
high calorific value is necessary to preheat the furnace prior to the application of biogas combustion in the combustion furnace. The flameless combustion temperature of a biogas furnace is lower than traditional combustion throughout a combustion chamber. Several experimental and numerical studies have explored the fuel characteristics of biogas. In such studies, high-quality fuel such as $\mathrm{H}_{2}$ [18-22] is blended with biogas to improve the relatively poor combustion characteristics of biogas. Zhen et al. [18] experimentally investigated the effect of $\mathrm{H}_{2}$ addition on the characteristics of a biogas diffusion flame. They found that $\mathrm{H}_{2}$ addition significantly improved the stability of the biogas flame. The flame temperature increased and visible flame length reduced with increasing $\mathrm{H}_{2}$ addition ratios. Wei et al. [19] numerically investigated the effects of equivalence ratio, $\mathrm{H}_{2}$, and $\mathrm{CO}_{2}$ on the heat release characteristics of the premixed laminar biogas-hydrogen flames. The results showed that $\mathrm{OH}+\mathrm{H}_{2} \Leftrightarrow \mathrm{H}+\mathrm{H}_{2} \mathrm{O}$ was major endothermic reaction for biogas-hydrogen premixed flames. The total heat release was enhanced evidently with $\mathrm{H}_{2}$ addition. Non-premixed are widely applied in the industrial process, while the heat release rate of biogas flame is low, which obstructs the application of biogas in practical application. Therefore, the improvement of heat release characteristics of biogas flame at various condition are necessary.

The above results show that numerous studies have investigated the combustion characteristics of biogas premixed flame. Nevertheless, understanding the non-premixed combustion of a fuel in practical application is necessary. To utilize biogas in internal combustion engines, the unburnt composition $\mathrm{CO}_{2}$ or $\mathrm{N}_{2}$ is expected to be excluded from biogas. Therefore, mechanical biological treatment is needed to upgrade raw biogas and increase $\mathrm{CH}_{4}$ content in biogas. The high cost of such treatment process is unfavorable to the application of biogas as a fuel. Therefore, the direct application of raw biogas is more economic for engines or heat supply. The current research proposes biogas combustion under hydrogen-enriched and oxygen-enriched conditions as potential methods to improve biogas combustion. The non-premixed flames of biogas under various hydrogen-enriched and oxygen-enriched conditions are studied, and the combustion and heat release characteristics of biogas non-premixed flames are numerically investigated. A non-premixed combustion model of biogas is established. The GRI 3.0 mechanism with 53 species and 325 elementary chemical reactions is employed, and the P1 radiation model is considered. All elementary chemical reaction rates and heat release rates are programmed. To enhance the combustion and heat release characteristics, hydrogen addition and oxygen enriched combustion are selected for biogas combustion in future practical application. The mass contents of $\mathrm{CH}_{4}$ in biogas, hydrogen addition ratios, and oxygen enrichment levels are ranged from $35.3 \%$ to $58.7 \%, 0 \%$ to $50 \%$, and $21 \%$ to $35 \%$, respectively.

\section{Numerical Simulations}

A typical gaseous combustion cylindrical chamber with a diameter of $200 \mathrm{~mm}(r)$ and $600 \mathrm{~mm}$ length $(z)$ is employed in this research, as shown in Figure 1. The fuel inlet is located at a central nozzle with a radius of $6.8 \mathrm{~mm}$, and air inlet is surrounded with a fuel inlet with a radius of $100 \mathrm{~mm}$. Three kinds of biogas fuel are applied in this research. The $\mathrm{H}_{2}$ addition ratio to fuel $\left(\mathrm{X}_{\mathrm{H}_{2}}\right.$, based on low heat value) and $\mathrm{O}_{2}$-enriched level $\left(\Omega_{\mathrm{O}_{2}}\right)$ are defined as following equations:

$$
\begin{gathered}
X_{\mathrm{H}_{2}}=\frac{V_{\mathrm{H}_{2}} \times L H V_{\mathrm{H}_{2}}}{V_{\mathrm{CH}_{4}} \times L H V_{\mathrm{CH}_{4}}+V_{\mathrm{H}_{2} \times L H V_{\mathrm{H}_{2}}}} \\
\Omega_{\mathrm{O}_{2}}=\frac{V_{\mathrm{O}_{2}}}{V_{\mathrm{O}_{2}}+V_{\mathrm{N}_{2}}}
\end{gathered}
$$

where $V_{\mathrm{CH}_{4}}, V_{\mathrm{H}_{2}}, V_{\mathrm{O}_{2}}$, and $V_{\mathrm{N}_{2}}$ are the flow rates of $\mathrm{CH}_{4}, \mathrm{H}_{2}, \mathrm{O}_{2}$, and $\mathrm{N}_{2}$ respectively; $L H V_{\mathrm{H}_{2}}$ and $L H V_{\mathrm{CH}_{4}}$ are the low heat values of $\mathrm{H}_{2}$ and $\mathrm{CH}_{4}$. The inlet fuel and oxidizer conditions at various $\mathrm{H}_{2}$-enriched condition and $\mathrm{O}_{2}$-enriched condition are shown in Table 1. The inlet power is kept constant under all calculation conditions. The mass contents of $\mathrm{CH}_{4}$ in biogas are $35.3 \%, 45.9 \%$, and 
$58.7 \%$, namely BG-1, BG-2, and BG-3, respectively. $\mathrm{H}_{2}$ addition ratio to biogas is arranged from $10 \%$ to $50 \%$, and $\mathrm{O}_{2}$ in the oxidizer is from $21 \%$ to $35 \%$.

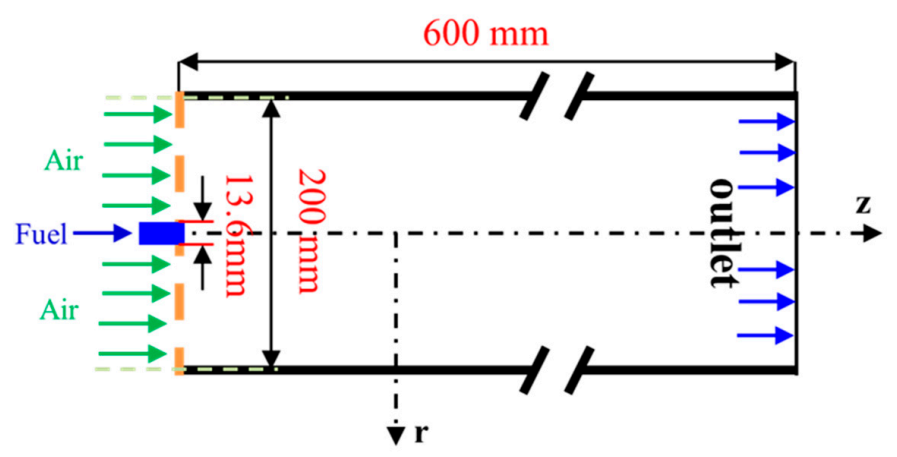

Figure 1. Geometry of the combustion chamber (not to scale).

Table 1. Composition of biogas flames at $\mathrm{H}_{2}$-enriched and $\mathrm{O}_{2}$-enriched conditions.

\begin{tabular}{ccccccc}
\hline Items & $\mathbf{C H}_{\mathbf{4}} / \mathbf{L} \cdot \mathbf{m i n}$ & $\mathbf{C O}_{\mathbf{2}} / \mathbf{L} \cdot \mathbf{m i n}^{-\mathbf{1}}$ & $\mathbf{H}_{\mathbf{2}} / \mathbf{L} \cdot \mathbf{m i n}^{-\mathbf{1}}$ & $\mathbf{O}_{\mathbf{2}} / \mathbf{L} \cdot \mathbf{m i n}^{-\mathbf{1}}$ & $\mathbf{A i r} / \mathbf{L} \cdot \mathbf{m i n}$ & Power/kW \\
\hline BG-1 & 1.829 & 1.220 & - & - & 18.340 & 1 \\
BG-2 & 1.829 & 0.784 & - & - & 18.340 & 1 \\
BG-3 & 1.829 & 0.457 & - & - & 18.340 & 1 \\
$\mathrm{H}_{2} 10 \%$ & 1.647 & 1.098 & 0.602 & - & 18.014 & 1 \\
$\mathrm{H}_{2} 30 \%$ & 1.281 & 0.854 & 1.805 & - & 17.361 & 1 \\
$\mathrm{H}_{2} 50 \%$ & 0.915 & 0.610 & 3.008 & - & 16.709 & 1 \\
$\mathrm{O}_{2} 25 \%$ & 1.829 & 1.220 & - & 0.780 & 14.626 & 1 \\
$\mathrm{O}_{2} 30 \%$ & 1.829 & 1.220 & - & 1.463 & 11.376 & 1 \\
$\mathrm{O}_{2} 35 \%$ & 1.829 & 1.220 & - & 1.950 & 9.054 & 1 \\
\hline
\end{tabular}

The flow mass, chemical species, momentum, and energy equation based on Navier-Stokes equations is expressed in Equation (3):

$$
\frac{\delta(\rho Y)}{\delta t}+\operatorname{div}(\rho \vec{V} Y)=\operatorname{div}\left(\Gamma_{Y} \operatorname{grad} Y\right)+S_{Y}
$$

where $\rho, Y, \vec{V}, \Gamma_{Y}$, and $S_{Y}$ are density, general dependent variable, velocity vector, associated transport coefficient of $Y$, and the source term. Thermal radiation is programmed to the source term of the mixture enthalpy. In this research, P1 radiation developed by Grosshandler of National Institute of Standards and Technology (NIST) [23] was selected. The gas radiation was considered by the determination of Planck mean absorption coefficient. Gas radiation contributed to the gases of $\mathrm{CH}_{4}$, $\mathrm{CO}_{2}, \mathrm{CO}$, and $\mathrm{H}_{2} \mathrm{O}$. The mean absorption coefficient of these gases $\left(\alpha_{i}\right)$ can be fitted as functions of temperature, which are summarized as Equations (4)-(6):

Mean absorption coefficient of $\mathrm{CH}_{4}$ :

$$
\alpha_{i}=a_{0}+a_{1} T+a_{2} T^{2}+a_{3} T^{3}+a_{4} T^{4}+a_{5} T^{5}
$$

Mean absorption coefficient of $\mathrm{CO}_{2}$ and $\mathrm{H}_{2} \mathrm{O}$ :

$$
\alpha_{i}=a_{0}+a_{1}\left(\frac{1000}{T}\right)+a_{2}\left(\frac{1000}{T}\right)^{2}+a_{3}\left(\frac{1000}{T}\right)^{3}+a_{4}\left(\frac{1000}{T}\right)^{4}+a_{5}\left(\frac{1000}{T}\right)^{5}
$$

Mean absorption coefficient of CO:

$$
\alpha_{i}=a_{0}+T\left\{a_{1}+T\left[a_{2}+T\left(a_{3}+a_{4} T\right)\right]\right\}
$$


The values of constants $a_{0}$ to $a_{5}$ for $\mathrm{CH}_{4}, \mathrm{CO}_{2}, \mathrm{CO}$, and $\mathrm{H}_{2} \mathrm{O}$ are shown in Table 2. The boundary wall is treated as a gray heat sink with emissivity of 0.8 , and the wall temperature is maintained at $300 \mathrm{~K}$ through water cooling. The total absorption coefficient of radiating gas mixture is calculated as the sum of the absorption coefficients of $\mathrm{CH}_{4}, \mathrm{CO}_{2}, \mathrm{CO}$, and $\mathrm{H}_{2} \mathrm{O}$ in the flame. All transport equations with radiation are solved by CFD software PHOENICS 2014 (Cham-Japan, Tokyo, Japan) [24]. The velocity and pressure coupling are treated by a SIMPLE method algorithm [25]. The GRI 3.0 mechanism with 53 species and 325 reactions [26] is applied to this research. The transport and thermal properties of all species are calculated by GRI 3.0 database and CHEMKIN codes. As a key parameter in fuel combustion, the heat release rates of all elementary reactions are defined and programed. Taking reaction R52 as example, we can calculate the heat release rate by following equations:

$$
\begin{gathered}
\mathrm{R} 52: \mathrm{H}+\mathrm{CH}_{3}(+\mathrm{M}) \Leftrightarrow \mathrm{CH}_{4}(+\mathrm{M}) \\
\Delta h_{i=52}=\left(h_{\mathrm{H}}+h_{\mathrm{CH}_{3}}\right)-h_{\mathrm{CH}_{4}}, \mathrm{~J} \cdot \mathrm{mol}^{-1} \\
q_{i=52}=\Delta h_{i=52} \times k_{i=52} \\
q_{\text {net }}=\sum_{i=1}^{325} q_{i}
\end{gathered}
$$

where $h_{j}$ is formation enthalpy of specie $j\left(\mathrm{~J} \cdot \mathrm{mol}^{-1}\right) ; \Delta h_{i}, k_{i}$, and $q_{i}$ are enthalpy change of reaction $i$ $\left(\mathrm{J} \cdot \mathrm{mol}^{-1}\right)$, the reaction rate of reaction $i\left(\mathrm{~mol} \cdot \mathrm{cm}^{-3} \cdot \mathrm{s}^{-1}\right)$, and heat release of reaction $i\left(\mathrm{~J} \cdot \mathrm{cm}^{-3} \cdot \mathrm{s}^{-1}\right)$, respectively. Furthermore, $q_{\text {net }}$ indicates the total heat release rate of all reactions $\left(\mathrm{mol} \cdot \mathrm{cm}^{-3} \cdot \mathrm{s}^{-1}\right)$.

Table 2. Absorption coefficient of $\mathrm{a}_{0}$ to $\mathrm{a}_{5}$ for $\mathrm{CH}_{4}, \mathrm{CO}, \mathrm{CO}_{2}$, and $\mathrm{H}_{2} \mathrm{O}$.

\begin{tabular}{cccccc}
\hline Coefficient & $\mathbf{C O}_{\mathbf{2}}$ & $\mathbf{H}_{\mathbf{2}} \mathbf{O}$ & $\mathbf{C H}_{\mathbf{4}}$ & $\mathbf{C O}(\mathbf{T}<\mathbf{7 5 0} \mathbf{K})$ & $\mathbf{C O}(\mathbf{T}>\mathbf{7 5 0} \mathbf{K})$ \\
\hline $\mathrm{a}_{0}$ & 18.741 & -0.23093 & 6.6334 & 4.7869 & 10.09 \\
$\mathrm{a}_{1}$ & -121.31 & -1.1239 & $-3.5686 \times 10^{-3}$ & -0.06953 & -0.01183 \\
$\mathrm{a}_{2}$ & 273.5 & 9.4153 & $1.6682 \times 10^{-8}$ & $2.95775 \times 10^{-4}$ & $4.7753 \times 10^{-6}$ \\
$\mathrm{a}_{3}$ & -194.05 & -2.9988 & $2.5611 \times 10^{-10}$ & $-4.25732 \times 10^{-7}$ & $-5.87209 \times 10^{-10}$ \\
$\mathrm{a}_{4}$ & 56.31 & 0.51382 & $-2.6558 \times 10^{-14}$ & $2.02894 \times 10^{-10}$ & $-2.5334 \times 10^{-14}$ \\
$\mathrm{a}_{5}$ & -5.8169 & $-1.884 \times 10^{-5}$ & 0 & - & - \\
\hline
\end{tabular}

\section{Discussion}

Figure 2 shows several typical measured outlet temperatures of BG-2/air flames with various $\mathrm{H}_{2}$ addition ratios and $\mathrm{O}_{2}$-enriched levels at the same input power of $1.0 \mathrm{~kW}$ and equivalence ratio of 0.95 ; the simulation results are shown for comparison. The outlet temperature was measured by a K-type thermocouple on a same combustion chamber and burner size with simulation, which was described in our previous study [27]. The error of experimental temperature at all $\mathrm{H}_{2}$ addition ratios and $\mathrm{O}_{2}$-eneriched levels are less than $15 \%$. Furthermore, the deviation of simulation and experimental results are below $11 \%$. Therefore, the simulation results show good agreement with experimental data at all $\mathrm{H}_{2}$ addition ratios and $\mathrm{O}_{2}$-enriched levels, thereby confirming that the GRI 3.0 mechanism provides an acceptable and repeatable result for biogas combustion under $\mathrm{H}_{2}$-enriched and $\mathrm{O}_{2}$-enriched conditions.

The effect of $\mathrm{CH}_{4}$ content in biogas fuel on the combustion temperature distribution is shown in Figure 3. The maximum combustion temperature increases with increasing $\mathrm{CH}_{4}$ content in biogas fuel. Furthermore, the flame length through the $z$-direction decreases at a higher $\mathrm{CH}_{4}$ content condition, and flame width through the $r$-direction also shrinks with increasing $\mathrm{CH}_{4}$ content in biogas fuel. These findings are attributed to the following explanations: (a) the reaction rate of elementary reactions in biogas fuel flames increases with increasing $\mathrm{CH}_{4}$ content in biogas fuel as shown in Figure 4, and is usually related to the flame structure; (b) the heat loss to heat up unburnt $\mathrm{CO}_{2}$ in biogas fuel gas decreases with higher $\mathrm{CH}_{4}$ content in biogas fuel; and (c) the total volume of combustion gas (including 
fuel gas and air) decreases when $\mathrm{CH}_{4}$ content in biogas fuel increases, leading to higher temperature and heat release rate under higher $\mathrm{CH}_{4}$ content condition. The maximum heat release rate increased by about $19.3 \%$ (from 362 to $432 \mathrm{~J} \cdot \mathrm{cm}^{-3} \cdot \mathrm{s}^{-1}$ ) with increasing $\mathrm{CH}_{4}$ content in biogas from BG-1 to BG-3, leading to a stronger heat release rate flame with shorter flame lengths at higher $\mathrm{CH}_{4}$ content in biogas fuel.

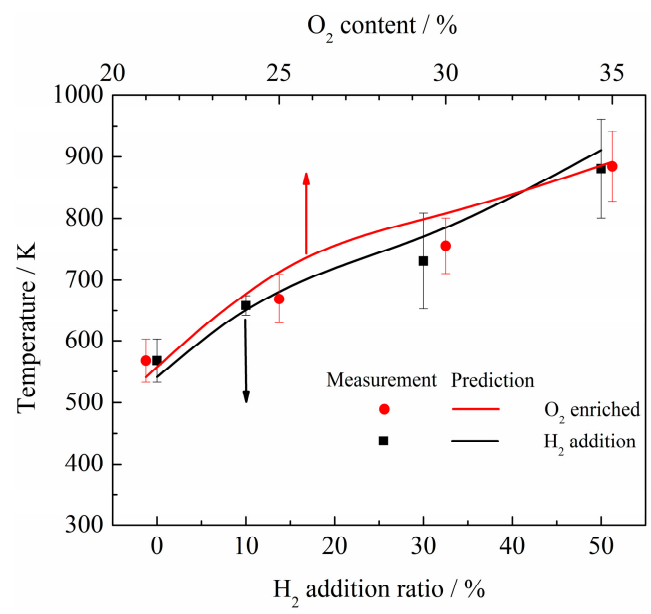

Figure 2. Comparison of predication temperature (line) and measurement temperature (plot) at the outlet of BG-2/air flames with various $\mathrm{H}_{2}$ addition ratios (black line) and $\mathrm{O}_{2}$ enrichment levels (red line).

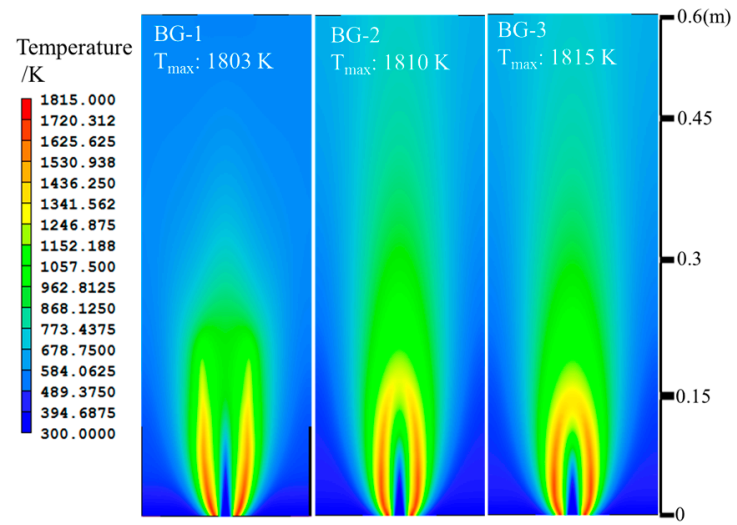

Figure 3. Effect of $\mathrm{CH}_{4}$ content in biogas fuel on combustion temperature distribution.

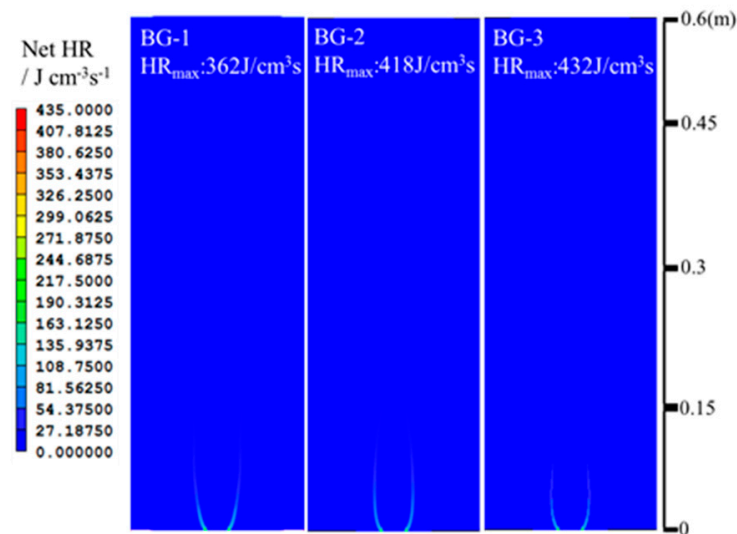

Figure 4. Effect of $\mathrm{CH}_{4}$ content in biogas fuel on net heat release rate distribution. 
The effects of $\mathrm{H}_{2}$ addition ratios and $\mathrm{O}_{2}$ enrichment levels in BG-2/air flame on combustion temperature distributions are shown in Figure 5. The maximum combustion temperature in flames increased by approximately $10.8 \%$ from 1803 to $1998 \mathrm{~K}_{\text {as }} \mathrm{H}_{2}$ addition ratio varied from $0 \%$ to $50 \%$, and was slightly higher by about $11.2 \%$ from 1803 to $2005 \mathrm{~K}_{\text {as }} \mathrm{O}_{2}$ enrichment levels increased from $21 \%$ to $35 \%$. Conversely, the maximum heat release rate in flames increased by 3.69 times from 362 to $1336 \mathrm{~J} \cdot \mathrm{cm}^{-3} \cdot \mathrm{s}^{-1}$ at $\mathrm{H}_{2}$ addition conditions and only 2.29 times from 362 to $829 \mathrm{~J} \cdot \mathrm{cm}^{-3} \cdot \mathrm{s}^{-1}$ under $\mathrm{O}_{2}$ addition conditions, as shown in Figure 6. This difference is also related to the shape and structure of biogas flames, which is important in the direct application of biogas for heating. Specifically, the position of maximum heat release rate varying with $\mathrm{H}_{2}$ addition and $\mathrm{O}_{2}$ enrichment is different. At the $\mathrm{H}_{2}$ addition condition, the fuel composition at fuel inlet varies with $\mathrm{H}_{2}$ addition rate, the fuel combustion velocity enhances because of high reactivity (more $\mathrm{OH}$ and $\mathrm{H}$ radicals with higher formation rate because of high burning velocity [28-30] and combustion temperature of $\mathrm{H}_{2}$ ) and high mobility of $\mathrm{H}_{2}$ [28-30]. Therefore, the maximum heat release rate at the $\mathrm{H}_{2}$ addition conditions is located at center of the flame. At the $\mathrm{O}_{2}$ enrichment condition, the fuel composition keeps constant, and the air composition at outside of fuel inlet varies with $\mathrm{O}_{2}$ enrichment. The fuel combustion velocity also improves because of the higher collision rate of oxidizer with fuel near flame edges. Therefore, the maximum heat release rate locates near the flame edges at $\mathrm{O}_{2}$ enriched condition.
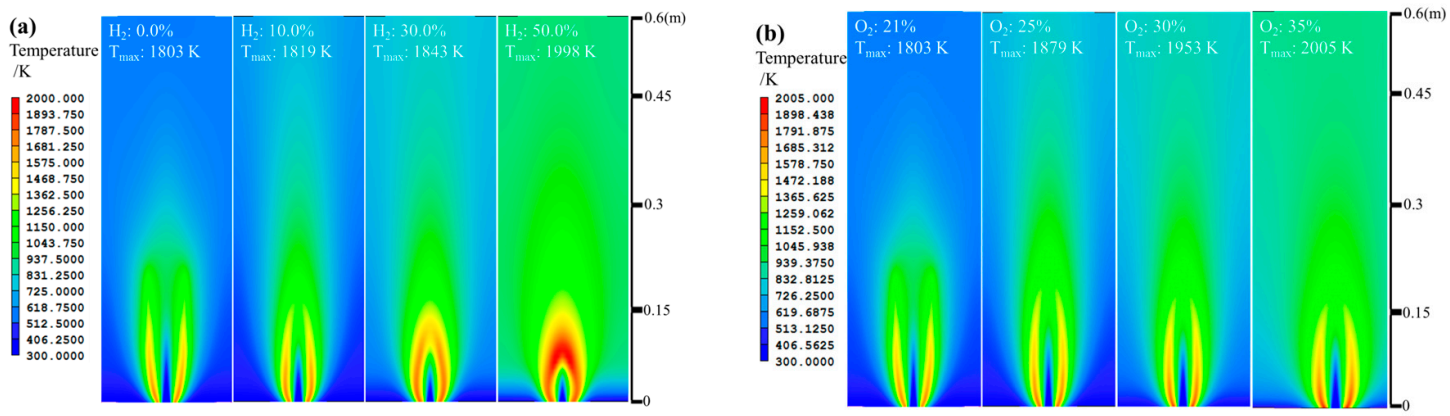

Figure 5. Effects of $\mathrm{H}_{2}$ addition ratio (a) and $\mathrm{O}_{2}$ enrichment levels (b) in BG-2/air flame on the distribution of combustion temperature.
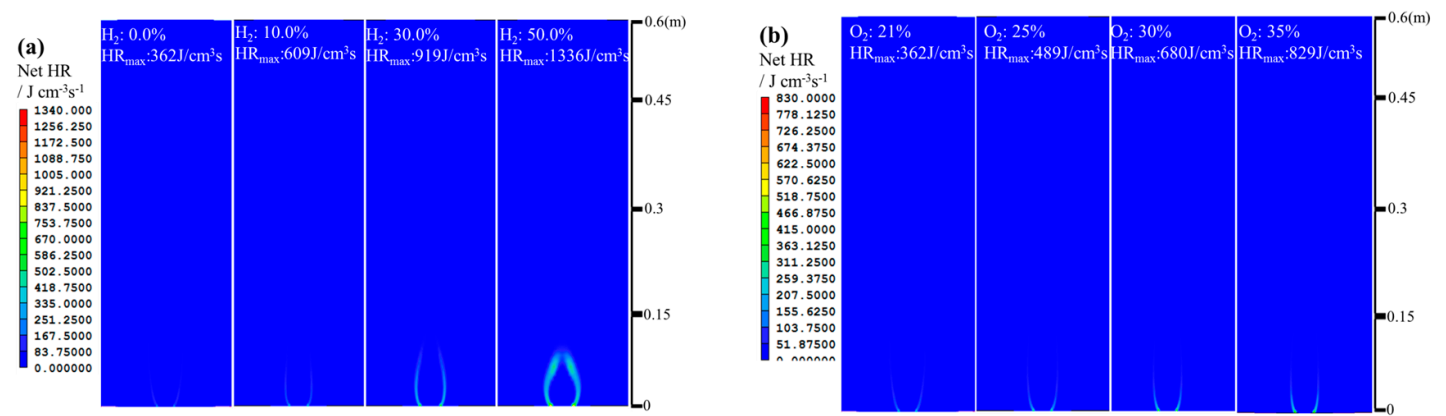

Figure 6. Effects of $\mathrm{H}_{2}$ addition ratio (a) and $\mathrm{O}_{2}$ enrichment levels (b) in BG-2/air flame on the distribution of the heat release rate.

To obtain an in-depth understanding of heat release characteristics of biogas flames under $\mathrm{H}_{2}$-enriched and $\mathrm{O}_{2}$-enriched conditions, the net heat release rate distribution at centerline along the $z$-direction is shown in Figure 7. The maximum net heat release rate at centerline is enhanced by approximately two orders of magnitude (from 0.155 to $120.0 \mathrm{~J} \cdot \mathrm{cm}^{-3} \cdot \mathrm{s}^{-1}$ ) when $\mathrm{H}_{2}$ addition ratio increases from $0 \%$ to $50 \%$; and the maximum net heat release rate at centerline is enhanced by about one order of magnitude (from 0.155 to $3.66 \mathrm{~J} \cdot \mathrm{cm}^{-3} \cdot \mathrm{s}^{-1}$ ) when the $\mathrm{O}_{2}$ addition ratio increases from $21 \%$ to $35 \%$. The enhancement of the heat release rate can lead to a change in flame structure and heat release characteristics in the flame reaction zone. Therefore, average temperature $T_{a}$ was defined 
to explore the effect of $\mathrm{H}_{2}$-enriched and $\mathrm{O}_{2}$-enriched conditions on flame kernel. $T_{a}$ is based on the barycenter of heat release rate as follows:

$$
T_{a}=\frac{\int_{0}^{z} q T \mathrm{~d} z}{\int_{0}^{z} q \mathrm{~d} z}
$$

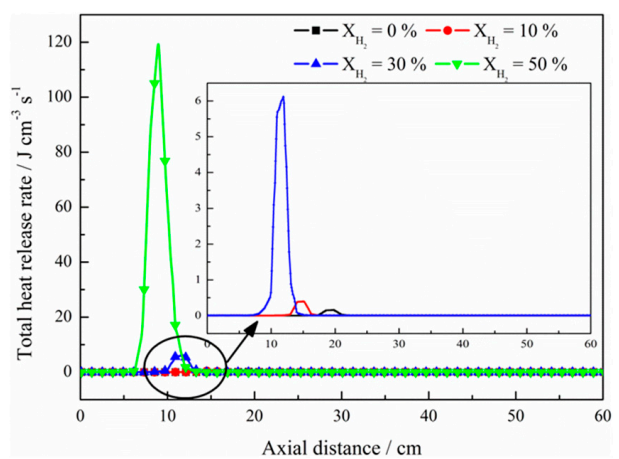

(a)

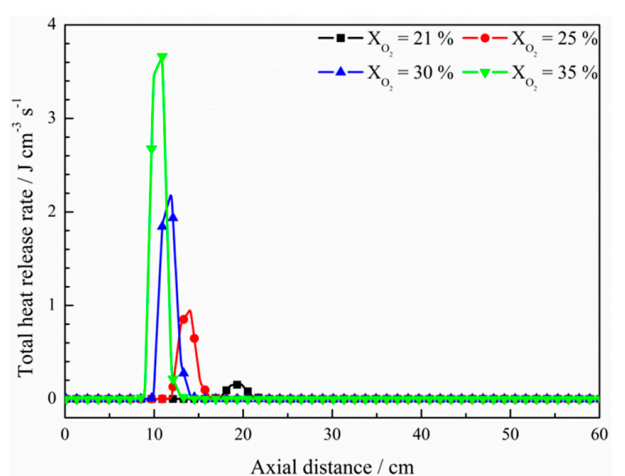

(b)

Figure 7. Heat release rate of biogas flames under $\mathrm{H}_{2}$-enriched (a) and $\mathrm{O}_{2}$-enriched (b) conditions along the centerline.

Figure 8 shows the average temperature $T_{a}$ together with flame height of peak heat release rate at various $\mathrm{H}_{2}$ addition ratios and $\mathrm{O}_{2}$ enrichment levels. As shown in Figure 8, the average temperature $T_{a}$ shows a gradual decrease with the increasing $\mathrm{H}_{2}$ addition ratio and $\mathrm{O}_{2}$ enrichment levels. For the biogas flame at same input power of $1 \mathrm{~kW}$ and equivalence ratio of 0.95 , the value of average temperature $T_{a}$ increases from 1215 to $1864 \mathrm{~K}$, nearly yielding an enhancement of $53.4 \%$, when $\mathrm{H}_{2}$ addition ratio varied from $0 \%$ to $50 \%$. In contrast, the flame height of peak heat release rate decreases by approximately $54.5 \%$ from 19.8 to $9.0 \mathrm{~cm}$ when the $\mathrm{H}_{2}$ addition ratio increases from $0 \%$ to $50 \%$. The enhancement of average temperature $T_{a}$ and reduction of flame height of maximum heat release rate resulted from the high mobility and high reactivity of $\mathrm{H}_{2}$, leading to a higher reaction rate of biogas flame under $\mathrm{H}_{2}$-enriched condition as shown in Figure 9a. By contrast, the value of average temperature $T_{a}$ increased from 1215 to $1428 \mathrm{~K}(\sim 17.5 \%$ increase) and the flame height of peak heat release rate decreases from 19.8 to $10.9 \mathrm{~cm}\left(\sim 44.9 \%\right.$ decrease) when $\mathrm{O}_{2}$ enrichment levels increased from $21 \%$ to $35 \%$. With the enrichment of $\mathrm{O}_{2}$ in combustion air, the reaction rate can be improved as shown in Figure 9b. Furthermore, unnecessary sensible heat to heat up the unburnt $\mathrm{N}_{2}$ gas also decreases with increasing $\mathrm{O}_{2}$ enrichment levels. As shown in Figure 9, the net reaction rate of biogas flames under the $\mathrm{H}_{2}$-enriched condition markedly increases as $\mathrm{H}_{2}$ addition ratio increases from $0 \%$ to $50 \%$ and lower increase is observed under $\mathrm{O}_{2}$-enriched condition when $\mathrm{O}_{2}$ levels increases from $21 \%$ to $35 \%$. To clarify the main elementary reaction in biogas flame, we compared the typical elementary exothermic reaction rate of biogas flame along the centerline at $\mathrm{H}_{2}$ addition ratio of $0 \%$ and $50 \%$ in Figure 10. The formation of free radicals, such as $\mathrm{H}, \mathrm{O}$, and $\mathrm{OH}$, are enhanced with the increase in hydrogen addition ratios; in particular, $\mathrm{R} 83: \mathrm{OH}+\mathrm{H}_{2} \Leftrightarrow \mathrm{H}+\mathrm{H}_{2} \mathrm{O}$ markedly increases as $\mathrm{H}_{2}$ is added to biogas flame, similar results have been reported for the heat release rate of premixed laminar biogas- $\mathrm{H}_{2}$ flame by Wei et al. [19] and $\mathrm{CH}_{4}$ /air premixed flames with $\mathrm{H}_{2}$ addition by $\mathrm{Hu}$ et al. [31]. Furthermore, the typical elementary exothermic reaction rates of $\mathrm{R} 83: \mathrm{OH}+\mathrm{H}_{2} \Leftrightarrow \mathrm{H}+\mathrm{H}_{2} \mathrm{O}$; R37: $\mathrm{H}+\mathrm{O}_{2} \Leftrightarrow \mathrm{O}+\mathrm{OH}$ are important to enhance biogas combustion. The elementary reaction of R83 $\left(\mathrm{H}_{2}\right.$ as reactant $)$ is higher than $\mathrm{R} 37\left(\mathrm{O}_{2}\right.$ as reactant). Therefore, $\mathrm{H}_{2}$ addition has a drastic effect on heat release rate (and reaction rate) enhancement than $\mathrm{O}_{2}$ enrichment as shown in Figures 6 and 7. The enhancement reaction rate can lead to structure and shape changes in biogas flame. The flame thickness along centerline under $\mathrm{H}_{2}$-enriched conditions and $\mathrm{O}_{2}$-enriched conditions are shown in Figure 11. The definition of flame thickness can be expressed as follows: 


$$
D_{F}=\frac{T_{\max }-T_{0}}{(d T / d z)_{\max }}
$$

where $T_{\max }$ and $T_{0}$ are the maximum temperature and unburned temperature respectively, $(d T / d z)_{\max }$ is the peak gradient in temperature profile along the centerline. As shown in Figure 11, the flame thickness decreases with the increasing $\mathrm{H}_{2}$ addition ratio and $\mathrm{O}_{2}$ enrichment levels. This decrease can be attributed to the burning velocity enhancement of biogas flames under $\mathrm{H}_{2}$-enriched and $\mathrm{O}_{2}$-enriched conditions. Therefore, a flame with enhanced heat release rate is formed under $\mathrm{H}_{2}$-enriched and $\mathrm{O}_{2}$-enriched conditions, which are beneficial to the practical application of biogas as a fuel.

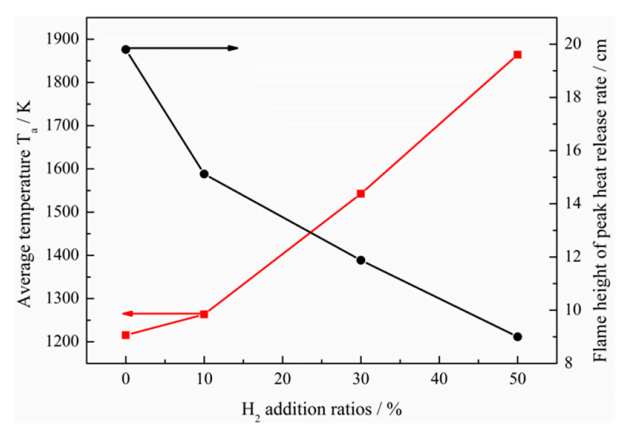

(a)

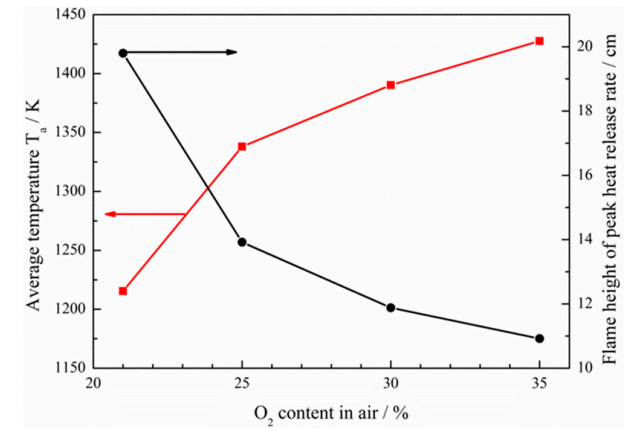

(b)

Figure 8. Effects of $\mathrm{H}_{2}$ addition ratio (a) and $\mathrm{O}_{2}$ enrichment levels (b) in BG-2/air flame on the peak heat release height and average temperature $T_{a}$.

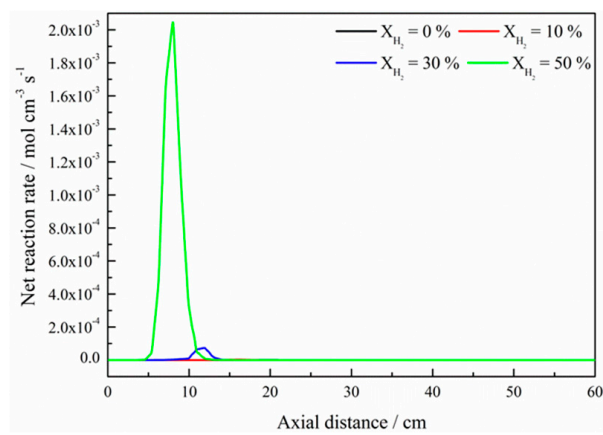

(a)

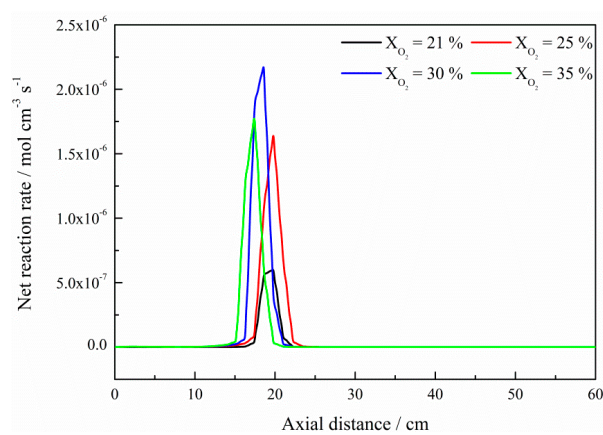

(b)

Figure 9. Net reaction rate of biogas flame along centerline at various $\mathrm{H}_{2}$ addition ratios (a) and $\mathrm{O}_{2}$ enrichment levels (b).

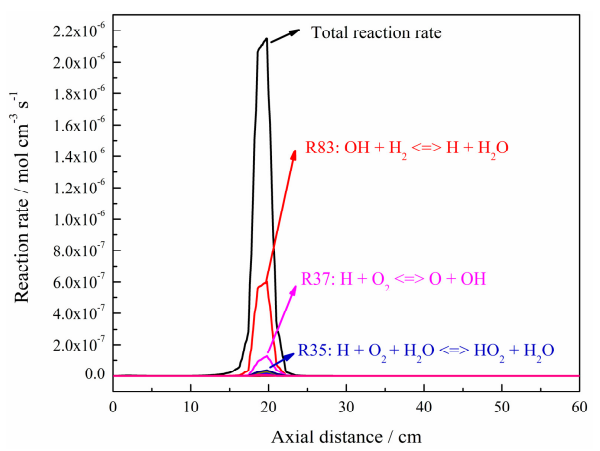

(a)

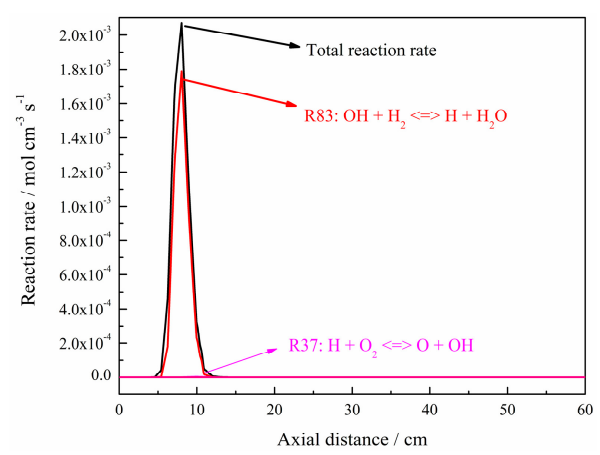

(b)

Figure 10. Comparison of typical elementary reaction exothermic reaction rates of biogas flame along the centerline at $\mathrm{H}_{2}$ addition ratio of $0 \%$ (a) and $50 \%$ (b). 


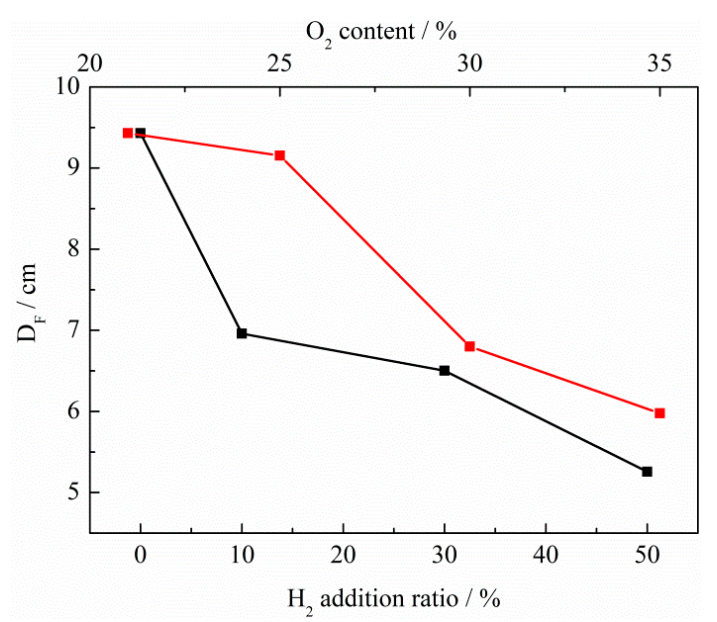

Figure 11. Flame thickness along the centerline at various $\mathrm{H}_{2}$ addition ratios (black line) and $\mathrm{O}_{2}$ enrichment levels (red line).

\section{Conclusions}

The combustion and heat release characteristics of biogas non-premixed flames under various hydrogen-enriched and oxygen-enriched conditions were investigated utilizing chemical kinetics simulation and the detailed chemical mechanism. The results are summarized as follows.

(1) The net reaction rate of biogas increases with increasing hydrogen addition ratio and oxygen levels, leading to a higher net heat release rate of biogas flame;

(2) The formation of free radicals, such as $\mathrm{H}, \mathrm{O}$, and particularly $\mathrm{OH}$, are enhanced with the increase in hydrogen addition ratio and oxygen levels;

(3) Flames with enhanced heat release rates are formed under $\mathrm{H}_{2}$-enriched and $\mathrm{O}_{2}$-enriched conditions. Therefore, $\mathrm{H}_{2}$-enriched and $\mathrm{O}_{2}$-enriched combustion is beneficial to the improvement of combustion and heat release characteristics of biogas in practical application.

Acknowledgments: This research is partially supported by the "Knowledge Hub Aichi" Priority Research Project from Aichi Prefectural Government, Japan.

Author Contributions: Jun Li contributed to the experiment and simulation, data analysis and paper writing; Hongyu Huang, Huhetaoli, Yu Bai, and Yong Chen contributed to experimental design, and Yugo Osaka and Noriyuki Kobayashi contributed to modeling selection and programing instruction.

Conflicts of Interest: The authors declare no conflict of interest.

\section{Nomenclature}

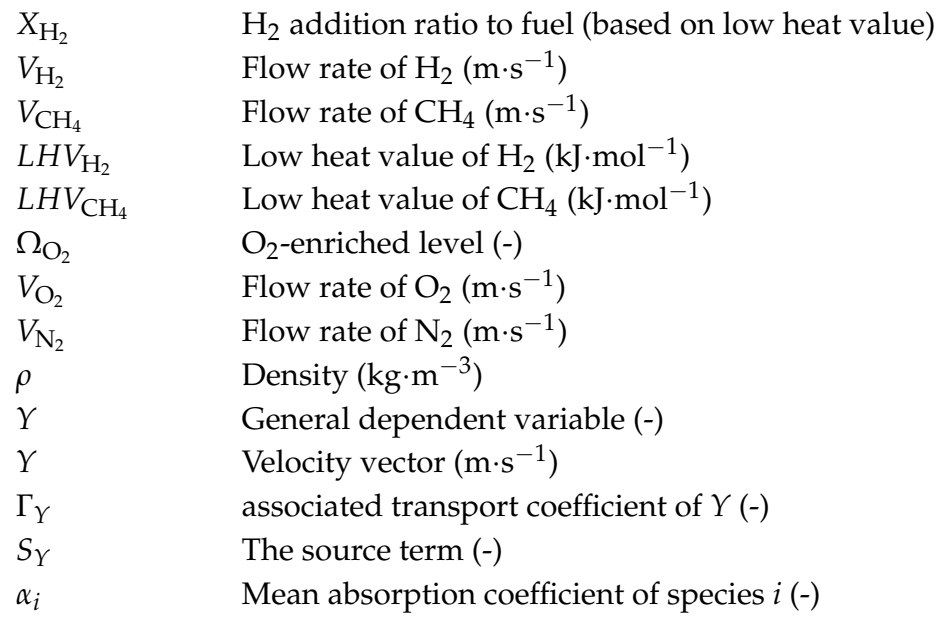




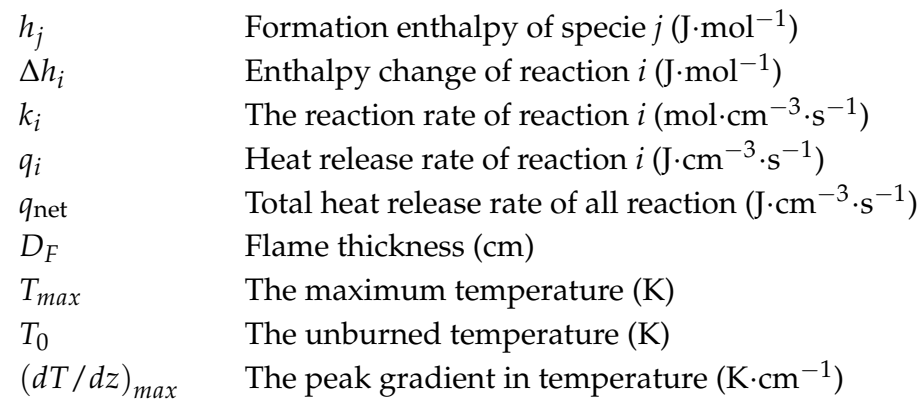

\section{References}

1. Divya, D.; Gopinath, L.R.; Christy, P.M. A review on current aspects and diverse prospects for enhancing biogas production in sustainable means. Renew. Sustain. Energy Rev. 2015, 42, 690-699. [CrossRef]

2. Pazera, A.; Slezak, R.; Krzystek, L.; Ledakowicz, S.; Bochmann, G.; Gabauer, W.; Helm, S.; Reitmeier, S.; Marley, L.; Gorga, F.; et al. Biogas in Europe: Food and Beverage (FAB) Waste Potential for Biogas Production. Energy Fuels 2015, 29, 4011-4021. [CrossRef]

3. Papurello, D.; Soukoulis, C.; Schuhfried, E.; Cappellin, L.; Gasperi, F.; Silvestri, S.; Santarelli, M.; Biasioli, F. Monitoring of volatile compound emissions during dry anaerobic digestion of the organic fraction of municipal solid waste by proton transfer reaction time-of-flight mass spectrometry. Bioresour. Technol. 2012, 126, 245-265. [CrossRef] [PubMed]

4. Papurello, D.; Lanzini, A.; Tognana, L.; Silvestri, S.; Santarelli, M. Waste to energy: Exploitation of biogas from organic waste in a $500 \mathrm{Wel}$ solid oxide fuel cell (SOFC) stack. Energy 2015, 85, 145-158. [CrossRef]

5. Papurello, D.; Silvestri, S.; Tomasi, L.; Belcari, I.; Biasioli, F.; Santarelli, M. Biowaste for SOFCs. Energy Procedia 2016, 101, 424-431. [CrossRef]

6. Bensaid, S.; Russo, N.; Fino, D. Power and hydrogen co-generation from biogas. Energy Fuels 2010, 24, 4743-4747. [CrossRef]

7. Wang, R.; Zhao, Z.; Liu, J.; Lv, Y.; Ye, X. Enhancing the storage stability of petroleum coke slurry by producing biogas from sludge fermentation. Energy 2016, 113, 319-327. [CrossRef]

8. Wang, J.; Xie, Y.; Cai, X.; Nie, Y.; Peng, C.; Huang, Z. Effect of $\mathrm{H}_{2} \mathrm{O}$ addition on the flame front evolution of syngas spherical propagation flames. Combust. Sci. Technol. 2016, 188, 1054-1072. [CrossRef]

9. Park, C.; Park, S.; Lee, Y.; Kim, C.; Lee, S.; Moriyoshi, Y. Performance and emission characteristics of a SI engine fueled by low calorific biogas blended with hydrogen. Int. J. Hydrogen Energy 2011, 36, 10080-10088. [CrossRef]

10. Fagbenle, R.; Oguaka, A.; Olakoyejo, O. A thermodynamic analysis of a biogas-fired integrated gasification steam injected gas turbine (BIG/STIG) plant. Appl. Therm. Eng. 2007, 27, 2220-2225. [CrossRef]

11. Galvagno, A.; Chiodo, V.; Urbani, F.; Freni, F. Biogas as hydrogen source for fuel cell applications. Int. J. Hydrogen Energy 2013, 38, 3913-3920. [CrossRef]

12. Shan, X.; Qian, Y.; Zhu, L.; Lu, X. Effects of EGR rate and hydrogen/carbon monoxide ratio on combustion and emission characteristics of biogas/diesel dual fuel combustion engine. Fuel 2016, 181, 1050-1057. [CrossRef]

13. Cacua, K.; Amell, A.; Cadavid, F. Effects of oxygen enriched air on the operation and performance of a diesel-biogas dual fuel engine. Biomass Bioenergy 2012, 45, 159-167. [CrossRef]

14. Baratieri, M.; Baggio, P.; Bosio, B.; Grigiante, M.; Longo, G. The use of biomass syngas in IC engines and CCGT plants: A comparative analysis. Appl. Therm. Eng. 2009, 29, 3309-3318. [CrossRef]

15. Fischer, M.; Jiang, X. An investigation of the chemical kinetics of biogas combustion. Fuel 2015, 150, 711-720. [CrossRef]

16. Somehsaraei, H.; Majoumerd, M.; Breuhaus, P.; Assadi, M. Performance analysis of a biogas-fueled micro gas turbine using a validated thermodynamic model. Appl. Therm. Eng. 2014, 66, 181-190. [CrossRef]

17. Hosseini, S.; Bagheri, G.; Wahid, M. Numerical investigation of biogas flameless combustion. Energy Convers. Manag. 2014, 81, 41-50. [CrossRef]

18. Zhen, H.; Leung, C.; Cheung, C. Effects of hydrogen addition on the characteristics of a biogas diffusion flame. Int. J. Hydrogen Energy 2013, 38, 6874-6881. [CrossRef] 
19. Wei, Z.; Leung, C.; Cheung, C.; Huang, Z. Effects of equivalence ratio, $\mathrm{H}_{2}$, and $\mathrm{CO}_{2}$ addition on the heat release characteristics of premixed laminar biogas-hydrogen flame. Int. J. Hydrogen Energy 2016, 41, 6567-6580. [CrossRef]

20. Mameri, A.; Tabet, F. Numerical investigation of counter-flow diffusion flame of biogas-hydrogen blends: Effects of biogas composition, hydrogen enrichment and scalar dissipation rate on flame structure and emissions. Int. J. Hydrogen Energy 2016, 41, 2011-2022. [CrossRef]

21. Zhen, H.; Leung, C.; Cheung, C.; Huang, Z. Combustion characteristic and heating performance of stoichiometric biogas-hydrogen-air flame. Int. J. Heat Mass Transf. 2016, 92, 807-814. [CrossRef]

22. Zhen, H.; Leung, C.; Cheung, C.; Huang, Z. Characterization of biogas-hydrogen premixed flames using Bunsen burner. Int. J. Hydrogen Energy 2014, 39, 13292-13299. [CrossRef]

23. Barlow, R. Radiation Models, Radiation, 2003. Available online: http:/ /www.ca.sandia.gov/TNF/radiation. html (accessed on 10 February 2016).

24. Spalding, D. New Developments and Computed Results, Imperial College CFDU Report HTS/81/1; Imperial College: London, UK, 1980.

25. Patankar, S. Numerical Heat Transfer and Fluid Flow; Hemisphere, CRC press: New York, NY, USA, 1980.

26. Smith, G. GRI-Mech. 1999. Available online: http://combustion.berkeley.edu/gri-mech/ (accessed on 23 November 2015).

27. Wu, L.; Kobayashi, N.; Li, Z.; Huang, H.; Li, J. Emission and heat transfer characteristics of methane-hydrogen hybrid fuel laminar diffusion flame. Int. J. Hydrogen Energy 2015, 40, 9579-9589. [CrossRef]

28. Tang, C.; Huang, Z.; Law, C. Determination, correlation, and mechanistic interpretation of effects of hydrogen addition on laminar flame speeds of hydrocarbon-air mixtures. Proc. Combust. Inst. 2011, 33, 921-928. [CrossRef]

29. Li, J.; Huang, H.; Kobayashi, N.; Wang, C.; Yuan, H. Numerical study on laminar burning velocity and ignition delay time of ammonia flame with hydrogen addition. Energy 2017, 126, 769-809. [CrossRef]

30. Li, Z.; Han, W.; Liu, D.; Chen, Z. Laminar flame propagation and ignition properties of premixed iso-octane/air with hydrogen. Fuel 2015, 158, 443-450. [CrossRef]

31. Hu, G.; Zhang, S.; Li, Q.; Pan, X.; Liao, S.; Wang, H.; Yang, C.; Wei, S. Experimental investigation on the effects of hydrogen addition on thermal characteristics of methane/air premixed flame. Fuel 2014, 115, 232-240. [CrossRef] 